\title{
Eighty Years of Resolutions
}

This is an index ${ }^{1}$ of the resolutions passed at Annual General Meetings of the Canadian Institute of Forestry/ Institut Forestier du Canada and its predecessor, the Canadian Society of Forestry Engineers since the founding of the C.S.F.E. and the A.G.M. of the CIF/IFC held in 1991.

This is not intended to be an analysis of resolutions nor a statement of the results of their implementation. Rather, it is prepared to help officers of the Institute determine what may have been the opinion of the membership in the past and, also, to assist Resolution Committees in their important task of structuring new resolutions annually.

This index is only a guide to finding resolutions. Those wishing to study them in detail will have to seek out the originals. Most are published in The Forestry Chronicle as part of the reports of AGMs. However, The Forestry Chronicle was not initiated until 1925 , so those of earlier years are reported in "A Short History of the C.S.F.E." by A.H.D. Ross, prepared in 1944. During the 1930's C.S.F.E. was compelled for financial reasons to reduce the size of The Forestry Chronicle and achieved this in part by publishing the ' C.S.F.E. News Bulletin', beginning in 1937. It was introduced as "A Supplement to the Forestry Chronicle'" and was continued for five years. Because it was designed to save money the reports of AGMs, including resolutions, were reported in it in 1938, 1939, 1940 and 1941 and were not printed in The Forestry Chronicle.

Before 1930 resolutions were limited to one or two annually. In 1930 a Resolutions Committee was established and there followed immediately a remarkable number of and improvement in the structure of resolutions.

This report does not include the usual resolutions of gratitude to hosts of annual meetings nor those that approve the actions of the Board of Directors. In all, over 400 resolutions have been dealt with in the 82 years and are classified here in about 55 subject groups.

\section{Acid rain}

- Endorsed the increased efforts of

\footnotetext{
'This issue includes the first part of the index; the remainder will be published in the next issue.
}

governments to assess the full impact of acid rain -1980

- Asked the federal government to eliminate at source atmospheric pollution in Canada as well as in the United States - 1989

\section{Annual General Meetings}

- Recommended that papers read at annual meetings be reduced in number -1933

- Urged establishment of a fund to assist members to attend AGMs 1939

- Requested the Executive Committee to recommend a method of proportional representation at AGMs 1939, 1940

- Regretted that no action had been taken to assist delegates to attend AGMs - 1940

- Resolved to fix and publish the dates of AGMs six months in advance 1941

\section{Armed Forces}

- Notified Voluntary Service Registration Bureau that C.S.F.E. members can provide valuable advice re developing a Forestry Corps for overseas service - 1940

- Requested acceleration of demobilization of technical foresters at cessation of hostilities - 1944

\section{Awards}

- Decided that CIF honor annually a deserving forester - 1961, 1963

- Agreed to appoint a committee to develop a superior achievement award at the Sectiion level - 1986

- Asked Executive Committee to explore establishment of an international forestry achievement award 1986

- Extended the Gold Medal to graduates of forestry colleges and institutes -1989

\section{Chemicals}

- Reviewed use of chemicals in forestry - 1977, 1981, 1982 (Nos. 2 \& 3), 1983

- Requested the team reviewing chemicals for use in forestry to include Forestry Canada as a member 1990

\section{CIF/IFC Policies}

- Resolved that officers be elected by letter ballot - 1911

- Agreed that the mail ballot for candidates for election to office be accompanied by appropriate resumes $-1933$

- Directed the Society to formulate definite forestry projects to place before governments for post-war action - 1941

- Decided that the name of the Institute will be bi-lingual - 1963

- Agreed to select a "Banner" issue for critical action - 1984

- Required a minimum of 50 members to establish a Section - 1985

- Established a formula for distribution of profits from Annual General Meetings between Host Section and Head Office - 1985, 1990

- Asked the Executive Committee to present to the Canadian Council of Forest Ministers annually a report on the Institute's concerns about forest management - 1986

- Promoted monitoring and implementation of the National Forest Sector Strategy - 1987

- Approved development of a strategic plan for the CIF/IFC for the next three years - 1987

- Supported the development of an annual forum for information exchange - 1987

- Directed the Institute to seek information and comments from interested parties re its strategic plan 1988

- Agreed to fund the attendance at AGMs of one student from each Canadian forestry school - 1988

- Requested all Institute members and committees to ensure that Canada's constitution recognizes the role of forests in Canadian society - 1991

\section{CIF/IFC Structures}

- Established an advisory committee for each of (1) Quebec, (2) Ontario, (3) the Prairie Provinces and (4) British Columbia - 1913

- Resolved that each Advisory Committee report annually to the Central Executive Committee - 1914

- Established an Executive Committee of President, Vice-President, Secretary Treasurer and 4 other members $-1915$ 
- Revised the Constitution - 1918

- Established a committee on research in two regions (east and west) 1920

- Appointed an Editorial Board 1926

- Approved that members in British Columbia form own branch -1927

- Approved development of a more effective structure for dealing with resolutions $-1930,1940,1962$, 1970, 1977, 1982

- Appointed a committee to assist in employment of foresters in forestry programs - 1933

- Reported that Ontario Section had first meeting January 22, 1935

- Appointed a committee to report on remuneration of the forestry profession in Canada - 1939

- Established an Editorial Baord to assist the Editor of The Forestry Chronicle - 1939

- Established a committee to consider employing one paid, full-time employee - 1940

- Revised the constitution to provide two-year terms of office for the President and Vice-president - 1940

- Established a sub-committee on logging in each region to cooperate with operators and associates there - 1941

- Established a committee to correlate post-war rehabilitation proposals to authorities - 1942

- Established eight technical committees - 1944

- Established a Committee on Forest Soils and Sites - 1950

- Set up a special committee on land tenure and taxation - 1950

- Established a committee to promote woodlot management - 1950

- Established a system to keep Executive Committee informed on developments in forestry across Canada 1969

- Set up a committee to gather information on provincial regeneration programs - 1973

- Ruled that Section boundaries will coincide with boundaries of Provincial Associations of Professional Foresters - 1976

- Set up a forum for international forestry - 1982

\section{Ecological Reserves}

- Promoted their establishment 1973, 1977, 1979, 1983

- Requested establishment of a natural Areas Committee - 1971

\section{Employment}

- Suggested to the Prime Minister that relief labor be used for forestry work - 1934, 1935

- Requested that positions for Water and Land Use Engineers in the Public Service be broadened to include forestry and hydrology - 1971

- Requested governments to use unemployed to conduct forest work on public lands -1971

- Urged Federal Government to develop a multi-year job creation program in forestry sector -1984

- Recommended that job creation programs planned by Federal Government be coordinated with provinces $-1985$

- Urged the Prime Minister to establish with forest industry and provinces a national forest-in-training program - 1985

- Requested CCFM to support municipal job corps programs - 1987

\section{Endorsements of Programs of Other Organizations}

- Commended Ontario for improved management of Crown Lands - 1930

- Commended Dominion and Provincial governments for work in forest research -1930

- Commended Quebec Lands and Forests for advances in forest policy $-1930$

- Congratulated the Minister of the Interior for starting National Forest Inventory - 1930

- Endorsed Nova Scotia's new forest legislation - 1930

- Congratulated New Brunswick on constructing its Forestry and Geology Building - 1931

- Endorsed the Canadian Lumberman Association's campaign to promote Canadian woods - 1931

- Commended Dominion and Provincial governments for progress in forest resources inventory -1931

- Congratulated Ontario for amalgamating various divisions dealing with crown timberlands -1935

- Commended the Young Men's Youth Employment Scheme for its forestry operations in British Columbia and recommended its adoption by the Provinces and Dominion - 1937

- Commended the Prairie Farm Rehabilitation Act's work on shelter belts and recommended its continuation and extension - 1937
- Commended the Association of Forest Engineers of Quebec on its very excellent and comprehensive forest policy prepared for the Province of Quebec - 1939

- Approved with pleasure Canada's Post-War Rehabilitation and Construction Program - 1941, 1942, 1943, 1944, 1945

- Supported establishment of the Canada Forestry Act - 1949

- Studied legislation for the Canada Forestry Act - 1951

- Urged implementation of the Canada Forestry Act - 1953

- Commended the Government of Canada on the report of the Gordon Royal Commission - 1958

- Expressed pleasure that FAO's Forestry Division is to retain its status $-1958$

- Confirmed the principle of Composite Forestry Agreements - 1964, 1966

- Commented favorably on the report of the Man and Resources Conference -1973

- Lauded the program of Canada's Centre for Remote Sensing but urged that delays be overcome - 1973

- Congratulated the Metric Commission for its report -1974

- Approved the Youth Group Programs - 1979

- Commended authorities for establishing the new forestry compelx at Fredericton, New Brunswick - 1981

- Commended Ontario for its forest management programs - 1983

- Endorsed new forest management programs in Quebec - 1984

- Lauded the Advisory Council of Canada's Activities in advising the Minister of the Environment - 1984

- Endorsed Canada's three-year program to fund Canadian forestry schools - 1985

- Supprted mayors of Vancouver Island in their program to create employment - 1985

- Supported the CCFM's conservation policies in the National Forestry Sector Strategy - 1987

- Approved municipal forestry programs such as the Sault Ste Marie Job Corps proposal - 1987

- Supported the establishment and use of the data base for the Nature Conservancy of Canada - 1988

- Thanked the Prime Minister for establishing the Department of Forestry and offered cooperation and 
advice in developing its programs 1988

- Supported a proposal for a World Forestry Organization and urged Canada to invite the United Nations to locate the Headquarters in Canada $-1990$

\section{Federal-Provincial Agreements}

- Recommended holding a DominionProvincial Forestry Congress 1944, 1945

- Commended the Federal-Provincial Agreements for their programs in forest renewals - 1977, 1983, 1989

\section{Forest Land}

- Recommended establishment of resident populations in the forests of Canada - 1945

- Urged that sites of proposed reservoirs be cleared of forests before flooding - 1951, 1967

- Requested municipalities to include professional forestry advice in land use planning - 1974

- Deplored alienation of forest land 1980, 1981, 1982

\section{Forest Management}

Urged that all information about slash disposal be provided to timberland owners and industry - 1930

- Lauded Sections for their actions in promoting forest management 1950, 1967

- Resolved to promote woodlot management in Canada - 1950

- Made Recommendations to the Federal Government - 1960, 1977, 1980, 1981, 1983

- Requested that all provinces integrate pest management and forest management plans - 1986

- Attempted to persuade the Federal and Provincial governments to refine or develop strategic plans for management of the forest land base $-1988$

\section{Forest Maps}

- Established a committee to standardize forest maps -1913

\section{Forest Meteorology}

- Requested the Dominion Meteorological Service to establish forecasting bureaus to assist forest fire protection agencies - 1930

\section{Forest Policy}

- Assisted the Premier of New Brunswick form a provincial policy - 1916

- Requested Associate Chambers of Commerce to develop a national forest policy - 1930

- Commended Quebec Lands and Forests for advances in forest policy $-1930$

- Established a committee to consider calling a forest congress to discuss a national forest policy -1934

- Directed the Executive Committee to make public any recommendations regarding support of or opposition to any private or public forest policy 1939

- Directed the Society to exercise greater influence in developing government and private forest policies - 1939

- Requested the Society to obtain and correlate basic data on inventory, yield, drain of forest products, losses, etc., as a basis of appraising public or private forest policies - 1940

- Agreed to develop a forest policy as a basis to support regional policies 1940

- Directed the Society to concentrate on completing its forest policy in the coming year - 1941

- Requested the Maritime Section to study how stumpage reduction in New Brunswick operates in practice $-1942$

- Requested the Quebec Society of Forest Engineers to study stumpage reduction in Quebec - 1942

- Agreed to develop a national forest policy - 1978

\section{Forest Productivity}

- Urged that forest productivity be doubled in two decades - 1977, 1988

- Recommended that losses to productivity caused by fire, insects and diseases be reduced - 1950, 1981

- Urged the use of wood for energy to improve forests and their yield 1980

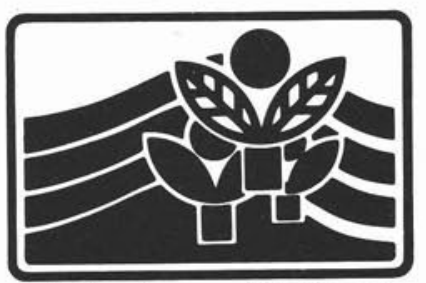

Ridgetown College

A CIF/IFC

Corporate Sustaining Member

\section{The Forestry Comical}

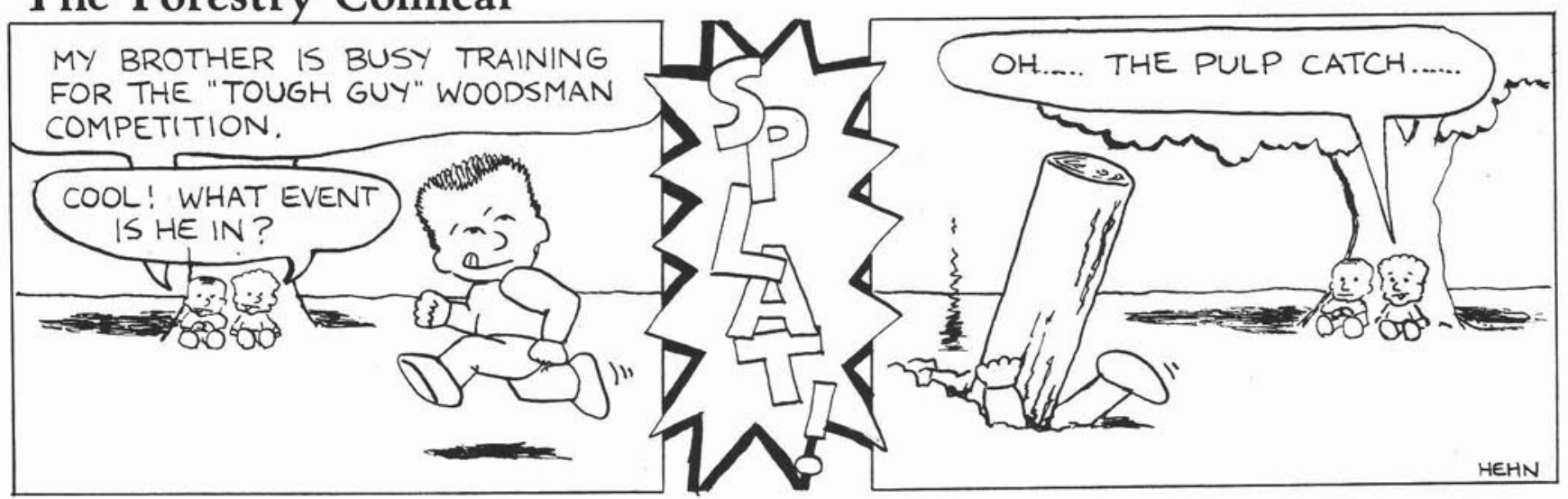

